\title{
AMENDMENTS TO THE ALIEN FLORA OF THE REPUBLIC OF MOLDOVA
}

\section{Csaba MolnáR ${ }^{1 *}$, András István Csathó ${ }^{2}$, Ábel Péter Molná ${ }^{3} \&$ Dániel PIFKó ${ }^{4}$}

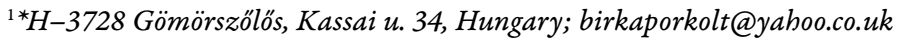 \\ ${ }^{2}$ H-5830 Battonya, Somogyi B. u. 42/A, Hungary \\ ${ }^{3}$ H-9400 Sopron, Mátyás király utca 20, Hungary \\ ${ }^{4}$ Department of Botany, Hungarian Natural History Museum, \\ H-1431 Budapest, Pf. 137, Hungary
}

Molnár, Cs., Csathó, A. I., Molnár, Á. P. \& Pifkó, D. (2019): Amendments to the alien flora of the Republic of Moldova. - Studia bot. hung. 50(1): 225-240.

\begin{abstract}
In this paper, eleven alien plant species are presented, two of them are reported for the first time in the Republic of Moldova (Euphorbia maculata, Gaillardia pulchella), one of them has so far been reported only from a botanical garden (Oenothera glazioviana), and eight species were previously known from a few localities in Moldova (Amaranthus powelii, Centaurea diffusa, Grindelia squarrosa, Gypsophila perfoliata, Ruta graveolens, Silphium perfoliatum, Sorghum halepense and Tragus racemosus). We also present an indigenous species which behaves as invasive (Rumex thyrsiflorus). We collected plants primarily on roadsides, along railway lines and in settlements, less often in natural habitats. Our goal is to report scattered data here. Voucher specimens were deposited in the Hungarian Natural History Museum, Botanical Department, Herbarium Generale (BP).
\end{abstract}

Key words: alien plants, invasive species, railway lines, road margins, synanthropic flora, urban flora

\section{INTRODUCTION}

Some alien species may become invasive, threatening natural and agricultural ecosystems, causing damages to the economy and human health (MCNEELY 2001, Wittenberg \& Cock 2001, Csiszár \& Korda 2015). Plant invasion is a rapid process, it is therefore important to be up to date. Our goal here is to contribute with scattered data to the knowledge of the flora of the study area. In the present paper we report two new alien species for the flora of the Republic of Moldova, as well as other, potentially invasive alien species, with insufficiently known distribution in the area.

The most complete summary on the synanthropic flora of the Republic of Moldova is provided by MÂRZA (2010) and MÂRZA et al. (2014). They reported altogether 189 alien plant species, of which 112 are neophytes. The proportion of 
neophytes in different habitats is higher than the European average (CHYTRÝ et al. 2009, MÂrZA 2010).

Since 2007 we have been studying the forest-steppe vegetation of the Republic of Moldova on several occasions and have been comparing it with the Carpathian Basin stands (MOlnár et al. 2008, 2012, Csathó 2014). During our studies, remarkable new occurrences of alien and anthropogenic species were found, which are reported in the present paper.

\section{MATERIAL AND METHODS}

Between 8 and 15 July 2018 we organized a field trip to the Republic of Moldova. We collected alien plants primarily on road margins, along railway lines and in settlements, less often in natural habitats. The collected specimens are unevenly distributed in the country and do not represent the distribution of the taxa there.

The geographic coordinates were recorded using Garmin GPSMAP 64. For larger populations, only one coordinate was recorded.

Voucher specimens are deposited in the Hungarian Natural History Museum, Botanical Department, Herbarium Generale (BP).

The morphological characters of the species were analysed on the specimens collected from the field and were compared with data from relevant literature sources (BÁTORI et al. 2012, NEGRU 2007, Tutin et al. 1960-1980, 1993, GEIDEMAN 1986, SÂRBU et al. 2013). The taxonomy and nomenclature of species follow Flora Europaea (Tutin et al. 1964-1980), except Oenothera glazioviana Micheli in Mart. (RostaŃski et al. 2010), but the more frequent synonyms are also provided here. Terminology and definitions recommended by EssL et al. (2018) and ABDULOYEVA \& KARPENKo (2012) were used for the status of alien plants.

\section{RESULTS}

New members of the adventive flora of Moldova

Euphorbia maculata L. [syn.: Chamaesyce maculata (L.) Small]

The species is native to North America (Gleason \& CronQUist 1991). It became naturalised in many places in South and Central Europe (SMIth \& Tutin 1968), Middle and South America, Middle East, Eastern Asia, New Zealand, and Australia (Holm et al. 1979, EsLER \& Astridge 1987), mainly in urban environments, road margins, fissures in roads, on railroad rocks, gardens, and other open, sunny locations. 
E. maculata is an annual herb, $10-17 \mathrm{~cm}$ tall and usually prostrate. Plants are hairy (sometimes only sparsely or inconspicuously). Leaves are (1.5-)2-3(-4) times as long as wide. Cyathia are not grouped at the end of stems. Capsule is uniformly hairy, with \pm appressed hairs. Seed is not blackish, at most dark grey or dark brown and evidently rugose (with 3-5 transverse grooves). Further morphological data and determination keys were published by SMITH \& Tutin (1968) and BÁTORI et al. (2012).

We found this species on railroad rocks in two places in Moldova.

1. Gagauzia, Bugeac (Bucak, Буджяк), Komrat railway station, $46.36058^{\circ} \mathrm{N}$, $28.65056^{\circ} \mathrm{E}$ (13 July 2018) (BP) (together with Gypsophila perfoliata L., Tribulus terrestris L.).

2. Cahul District, Greceni (Гречень), along railroad tracks, $45.76758^{\circ} \mathrm{N}$, $28.52750^{\circ}$ E (14 July 2018) (BP) [with Aegilops cylindrica Host, Grindelia squarrosa (Pursh) Dunal, Plantago arenaria Waldst. \& Kit., Tragus racemosus (L.) All., Tribulus terrestris L.] (Fig. 1).

We have not found any previous records of this species from the country. In this region, the species was first found in Ukraine (DUBYNA \& PROTopopova

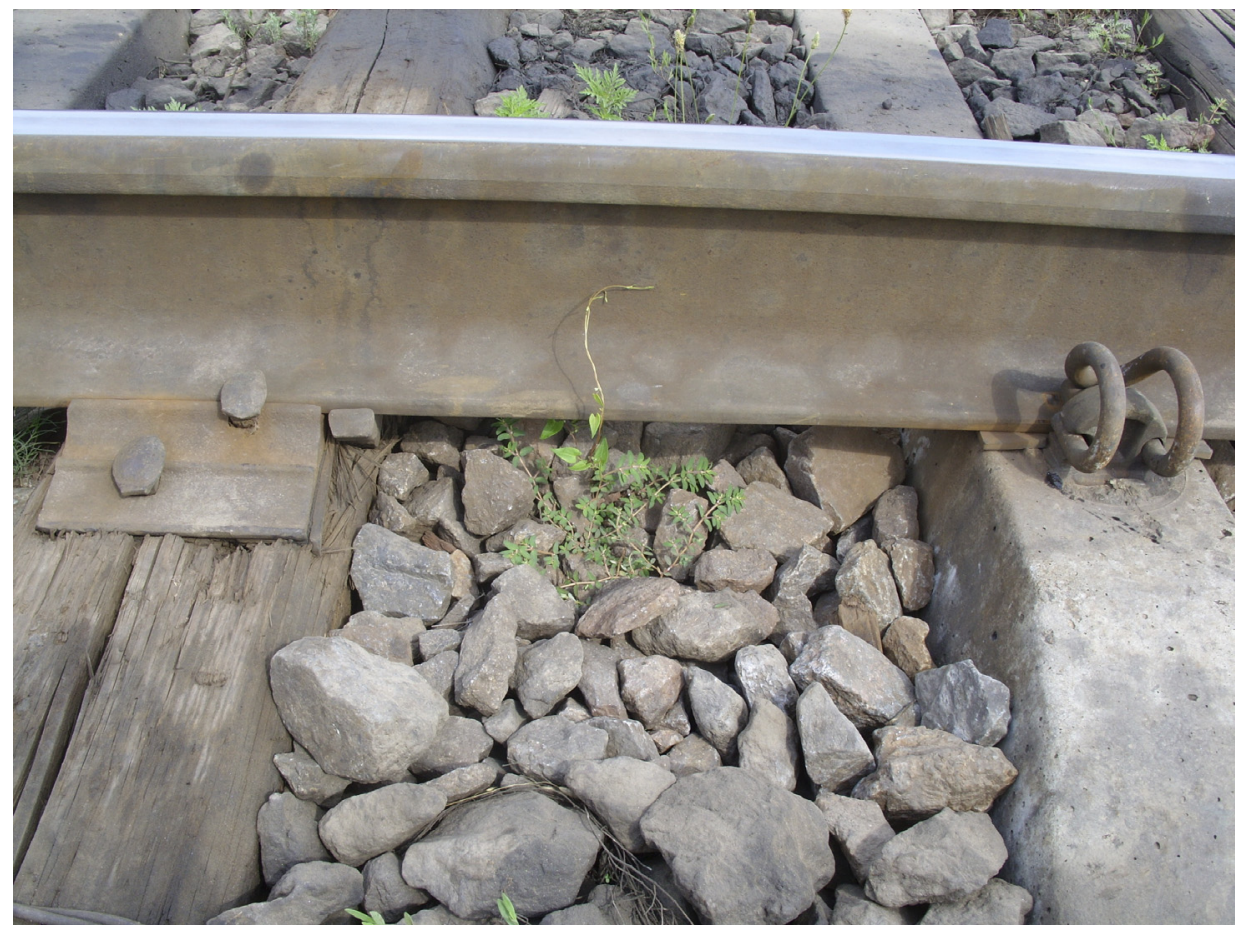

Fig. 1. Euphorbia maculata near Greceni. 
1984, Popova 2003). It is known along the shores of the Black Sea and in the Danube Delta (ANASTASIU et al. 2014), however, in other areas, west and south of Moldova, the species is typically connected to roads and railways, so in Bulgaria (Petrova et al. 2013), in Romania (Goga 1960), in Hungary (Degen 1907), and in Slovakia (ELIÁš 2009).

\section{Gaillardia pulchella Foug.}

The species is native to North America, planted worldwide as an ornamental plant. It has occasionally been naturalised in Macaronesia, southern Africa, China, Eastern Asia, southeastern and southwestern Europe, the Pacific Islands, and the Caribbean. An adventive species in Europe, and in Central Europe it behaves invasively (HANSEN 1976a, WIERSEMA \& LEÓN 2013).

Another species of the genus $G$. aristata Pursh is also widely planted in Europe. The breeders also created many variants and even hybrids of the two species, so the clear identification of specimens is sometimes not easy. The individuals we collected are annual, smaller in size, $30-50 \mathrm{~cm}$ tall, petals are ca $30-40 \mathrm{~mm}$ long, the inflorescence is bicolorous, red in the middle, yellow at the margin and the whole plant is covered with soft hairs.

We found this species in two places in Moldova.

1. Criuleni District, near Mălăiești Noi (Мемзештий Ной), on Dniester plateau, some flowering plants in a fallow used for pasture, $47.08167^{\circ} \mathrm{N}, 29.13867^{\circ}$ E (11 July 2018) (BP).

2. Hîncești District, between Onești (Онешть) and Leușeni (Иеушень), some flowering plants along the roadside, $46.85100^{\circ} \mathrm{N}, 28.21189^{\circ} \mathrm{E}$ (12 July 2018) (BP) (Fig. 2).

We did not find any previous records of the species from the country. It is occasionally naturalised in Ukraine (MELNI K 2009) and Romania (CIOCÂRLAN 2009). In Hungary, we observed its invasive behaviour on sand, on dry, open surface, especially on fallow fields (Molnár et al. ined.). The population near Onești is in a similar environment like some Hungarian ones, thus its spread in Moldova is expected.

Oenothera glazioviana Micheli in Mart. (syn: Oe. erythrosepala Borbás)

The species is native to North America, but introduced to South America, Europe, East Asia, and other continents and islands, as an escaped ornamental plant. It has often subspontaneous populations, but rarely forms large monodominant stands. Often hybridizes with other adventive Oenothera taxa (RosTAŃs KI et al. 2010). 

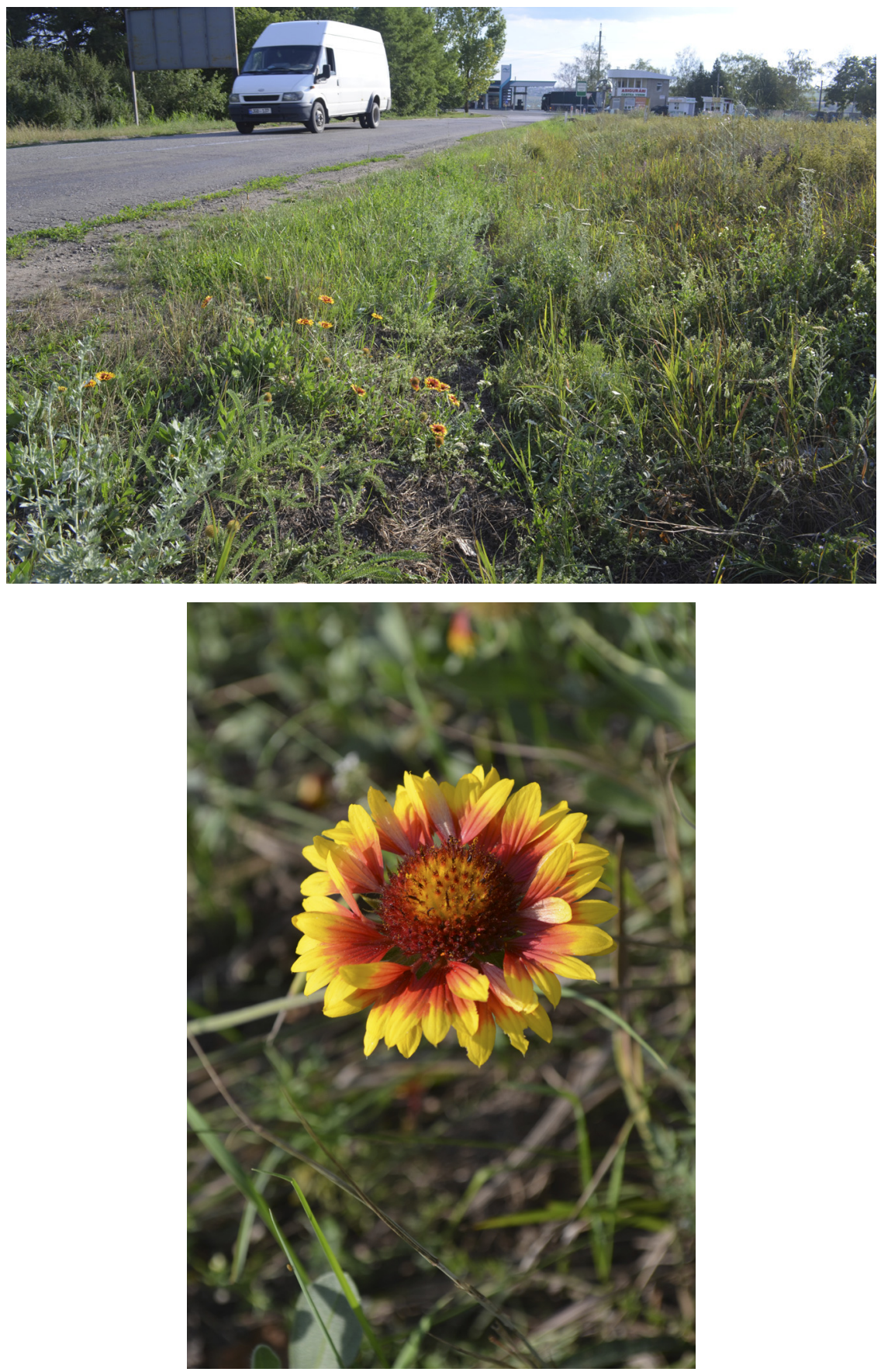

Fig. 2. Gaillardia pulchella between Onești and Leușeni. 


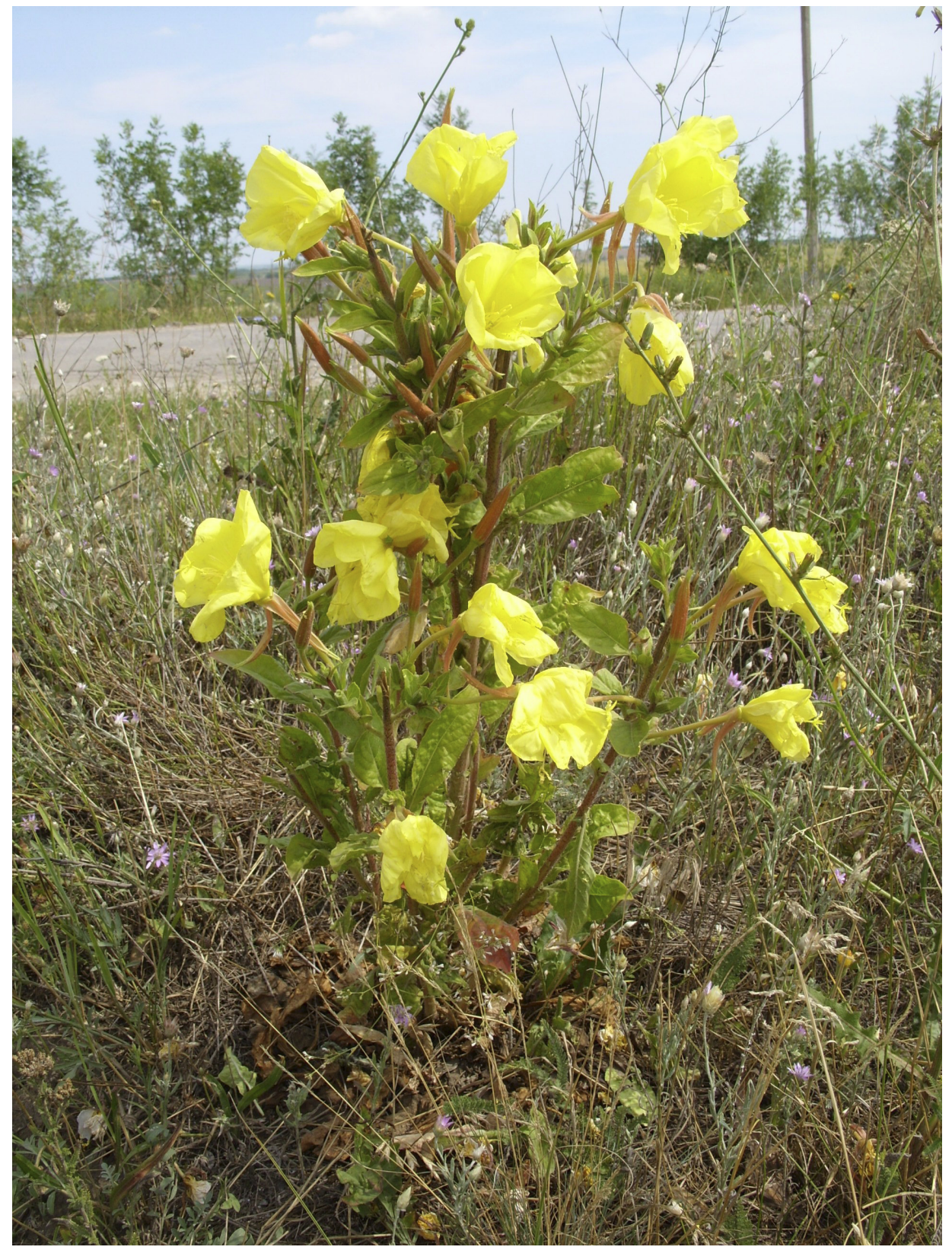

Fig. 3. Oenothera glazioviana between Greceni and Burlăceni. 
Oenothera glazioviana is a biennial herb, stem up to $180 \mathrm{~cm}$, simple or branched, green or reddish, strongly red spotted, with spreading short hairs and longer stiff hairs with red bulbous bases. Rhachis green but red-spotted. Buds red-striped when ripe, strongly glandular-pubescent. Sepal tips 3-8 mm. Hypanthium 30-40 mm. Petals broadly obcordate, 30-50 mm long, 32-58 mm broad, the largest within the genus. Further details and identification key were published by Rostańs Ki et al. (2010).

We found this species on road margin in one place in Moldova.

1. Cahul District, between Greceni (Гречень) and Burlăceni (Бурлзчень), on road margin, one flowering plant and some leaf rosettes, $45.75869^{\circ} \mathrm{N}, 28.51928^{\circ}$ E (14 July 2018) (BP) (Fig. 3).

This species has been reported only from a botanical garden in the Republic of Moldova, observed by SkvorTsov in the Botanical Garden (Grădina Botanică), in Chișinău, 1986 (SKvortsov 1994, Rostańs Ki 2004, Rostańs Ki et al. 2010). It is known nearby, next to Berheci (Galați County, Romania), along the roadside (SÎRBU \& OPREA 2010). Further stands in synanthropic habitats, ruderal places are known in Ukraine (e.g. Rostańs Ki et al. 2004, MELNIK 2009) and Romania (e.g. Sîrbu \& Oprea 2010, Pricop \& Negrea 2018) also.

\section{Records contributing to the flora of Moldova}

Amaranthus powelii S. Wats.

The species is native to North and South America. It is currently a weed spreading worldwide, from southwestern and Central Europe to all directions in Europe (AELlen \& Akeroyd 1993).

We found this species along roadsides in two places in Moldova.

1. Criuleni District, near Orhei Vechi Monastery, $47.30133^{\circ} \mathrm{N}, 28.971972^{\circ}$ E (11 July 2018).

2. Criuleni District, Ratuş (Ратуш), gas station and bus stop, $47.16911^{\circ} \mathrm{N}$, $28.80844^{\circ} \mathrm{E}$ (11 July 2018).

The species is missing in the list of NEGRU (2007), but later MÂRZA (2010) reported it from Moldova. It is still a rare weed in the country, but spreading also in the neighbouring Romania (e.g. Pricop \& Negrea 2018) and Ukraine (e.g. Protopopova et al. 2006, Melnik 2009).

\section{Centaurea diffusa Lam.}

This species is native to the eastern Mediterranean, Asia Minor, Iran, and Central Asia. It was naturalised in many places in South and Central Europe, 
North America, and the former Soviet Union, mainly in urban environment, waste places and fallow fields (Dostál 1976, Protopopova et al. 2006).

We recorded this species in eight places in Moldova, and did not find it infrequent in the country.

1. Bălți District, north of Sadovoe (СаАовое), in a loess-valley, $47.78542^{\circ} \mathrm{N}$, $27.82158^{\circ} \mathrm{E}$ (10 July 2018) (BP).

2. Sîngerei District, between Sîngereii Noi (СынАжереий Ной) and Rădoaia (Рэдоая), in weedy pasture, $47.72039^{\circ} \mathrm{N}, 28.11661^{\circ} \mathrm{E}$ (10 July 2018).

3. Sîngerei District, near Izvoare (Извоаре), in pasture, $47.71167^{\circ} \mathrm{N}$, $28.19553^{\circ} \mathrm{E}$ (10 July 2018 ).

4. Orhei District, near Slobozia (Слобозиа), at the edge of a quarry, $47.36172^{\circ} \mathrm{N}, 28.82456^{\circ} \mathrm{E}$ (10 July 2018).

5. Criuleni District, near Mălăiești Noi (Мелзештий Ной), on Dniester plateau, in grazed fallow fields, $47.08167^{\circ} \mathrm{N}, 29.13867^{\circ} \mathrm{E}$ ( 11 July 2018 ).

6. Criuleni District, near Ohrince (Охринча), in abandoned vineyard, $47.23158^{\circ} \mathrm{N}, 29.05014^{\circ} \mathrm{E}$ (11 July 2018).

7. Criuleni District, near Orhei Vechi Monastery, $47.30133^{\circ} \mathrm{N}, 28.97197^{\circ} \mathrm{E}$ (11 July 2018).

8. Hîncești District, near Pervomaiscoe (Первомайское), in abandoned vineyard and pasture, $46.90094^{\circ} \mathrm{N}, 28.33331^{\circ} \mathrm{E}$ (12 July 2018).

The species is included in the list of NEGRU (2007), and mentioned from many places in the country (MÂRzA 2010, Miron 2009, SHABANOVA et al. 2014). It is widespread also in Ukraine (Protopopova et al. 2006, ABDULOYEVA \& KARPENKo 2009, KRU Kova \& Bondarenko 2014, Denisow et al. 2017, MAMCHUR et al. 2017, PASH KEVYCH \& BURDA 2017) and sporadic in Romania (SÂRBU et al. 2013).

\section{Grindelia squarrosa (Pursh) Dunal}

The species is native to North America. It was formerly cultivated as a medicinal plant, and has been naturalised in waste places in Ukraine from 1949 (Protopopva et al. 2006). It has been spreading since then in new habitats and new areas (HANSEN 1976b).

We recorded this species in fourteen places in Moldova, especially along roadsides. It seems not infrequent in the country.

1. Glodeni District, Glodeni (ГАодень), city bypass, along the roadside, $47.79897^{\circ} \mathrm{N}, 27.50831^{\circ} \mathrm{E}$ (9 July 2018) (BP).

2. Bălți District, Bălți (Бэлць), along the roadside, $47.718500^{\circ} \mathrm{N}, 28.117417^{\circ}$ E (10 July 2018).

3. Chișinău District, between Chișinău (Кишинов) and Tohatin (Тохатин), along the roadside, $47.05292^{\circ} \mathrm{N}, 28.93725^{\circ} \mathrm{E}$ ( 11 July 2018 ). 
4. Criuleni District, near Mălăiești Noi (Мемзештий Ной), on Dniester plateau, in grazed fallow fields, $47.08167^{\circ} \mathrm{N}, 29.13867^{\circ} \mathrm{E}$ ( 11 July 2018 ).

5. Criuleni District, near Criuleni (Криумень), along roadsides, $47.20072^{\circ} \mathrm{N}$, $29.15222^{\circ} \mathrm{E}$ (11 July 2018).

6. Criuleni District, near Ohrincea (Охринча), along roadsides, $47.21597^{\circ}$ N, 29.06700 E (11 July 2018).

7. Criuleni District, near Mașcăuți (Машкэуць), along roadsides, $47.28864^{\circ}$ N, 28.98358 E (11 July 2018).

8. Criuleni District, near Morovaia (Моровая), along roadsides, $47.29822^{\circ}$ N, 28.98750 E (11 July 2018).

9. Criuleni District, near Orhei Vechi Monastery, $47.30133^{\circ} \mathrm{N}, 28.97197^{\circ} \mathrm{E}$ (11 July 2018).

10. Orhei District, near Brănești (Брэнешть), along roadsides, $47.29961^{\circ} \mathrm{N}$, $28.91333^{\circ} \mathrm{E}$ (11 July 2018).

11. Orhei District, near Furceni (Фурчень), along roadsides, $47.34094^{\circ} \mathrm{N}$, $28.91500^{\circ} \mathrm{E}$ (11 July 2018).

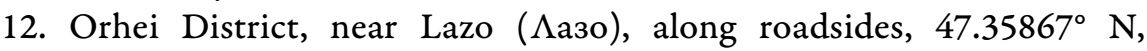
$28.89839^{\circ} \mathrm{E}$ (11 July 2018).

13. Criuleni District, Ratuș (Ратуш), in a gas station and bus stop, $47.16914^{\circ}$ N, 28.80844 E (11 July 2018).

14. Cahul District, Greceni (Гречень), along railroad tracks, $45.76758^{\circ} \mathrm{N}$, $28.5275^{\circ}$ E (14 July 2018 ).

The species is included in the list of NEGRU (2007), and mentioned from many places in the country (MÂRzA 2010). It is a newly detected alien in Moldova (MîRzA et al. 1987), but it is already a common species there (NEGRU et al. 2006, ShaBANOva et al. 2014). It was introduced from Ukraine, where it is a common alien plant (Protopopova et al. 2006, AbDuloyeVa \& KARPENKo 2009, Melni K 2009, Krukova \& Bondarenko 2014, Pash KeVyCH \& BuRdA 2017). Grindelia spreads from Ukraine eastward recently to Russia (HANSEN 1976b) and westward to Romania (Sîrbu \& Oprea 2008, Sînbu et al. 2012), Bulgaria (Vladimirov \& Petrova 2012, Petrova et al. 2013), and Slovakia (JEHLÍ́ et al. 2013). In addition, it is a casual alien in other European countries.

\section{Gypsophila perfoliata L.}

This Irano-Turanian species is a rare casual alien in Central and southeastern Europe (BARKoudah et al. 1993, Somlyay 2009).

We found this species on railroad rocks in one place in Moldova.

1. Gagauzia, Bugeac (Bucak, БуАжяк), Komrat railway station, $46.36058^{\circ} \mathrm{N}$, $28.65056^{\circ} \mathrm{E}$ (13 July 2018). 
The species is missing in the list of NEGRU (2007), but MÂRZA (2010) later reported it from the country. It is probably native to the Black Sea Coast (OPREA 2005), its closest known records are known from the Danube Delta (Popova 2003). Like other species of sandy substrates, it also appears next to the railway and roadside verge rocks, perhaps its further spread is expected. This is evidenced by the fact that it has recently been discovered in several locations in Poland (Święs \& Wrzesień 2002, Pliszko 2016), and in Romania (Chifu et al. 2006) from also railway stations.

\section{Ruta graveolens $\mathrm{L}$.}

The species is native to the Balkan Peninsula and Crimea. It is cultivated as a medicinal and ornamental plant in many countries of Europe. It frequently escaped from gardens and widely naturalised outside in southern and Central Europe (TOWNSEND 1968, OPREA 2005).

We recorded this species in trampled lawn in one place in Moldova.

1. Criuleni District, near Orhei Vechi Monastery, $47.30133^{\circ} \mathrm{N}, 28.97197^{\circ} \mathrm{E}$ (11 July 2018).

The species is not included in the list of NEGRU (2007), but reported subsequently by MÂRZA (2010).

\section{Silphium perfoliatum $\mathrm{L}$.}

The species is native to North America. It is cultivated elsewhere as an ornamental and a fodder plant. It occurs as a casual and locally naturalised species on river-banks and in damp meadows in Europe (Tutin 1976).

We found this species in one place in Moldova.

1. Bălți District, Bălți (Бэлць), along roadside, $47.77222^{\circ} \mathrm{N}, 27.86497^{\circ} \mathrm{E}(10$ July 2018) (BP).

The species is missing in the list of NegRU (2007), but MÂRZA (2010) reported it from Moldova recently. It is occasionally naturalised in Ukraine (e.g. YAKUBENKo et al. 2014), but missing in Romania (OPREA 2005, SÂRBU et al. 2013).

\section{Sorghum halepense (L.) Pers.}

The species is native to North Africa and southwestern Asia. It is possibly native to the eastern Mediterranean region. It is widely naturalised as a weed and ruderal species in southern and Central Europe (CLAYTON 1980).

We recorded this species in three places in Moldova, although it is not uncommon in the southern parts of the country, primarily in dry open habitats. 
1. Hîncești District, between Hîncești (Хынчешть) and Rusca (Русска), along roadside, $46.86347^{\circ} \mathrm{N}, 28.50589^{\circ} \mathrm{E}$ (12 July 2018 ).

2. Hîncești District, near Lăpușna ( Азпушна), along roadside, $46.88958^{\circ} \mathrm{N}$, $28.36869^{\circ} \mathrm{E}$ (12 July 2018 ).

3. Taraclia District, near Ciumai (Чумай), in sand pit, $45.78878^{\circ} \mathrm{N}$, $28.55575^{\circ} \mathrm{E}$ (14 July 2018).

The species is included in the list of NEGRU (2007) and mentioned from more places by MÂRZA (2010).

\section{Tragus racemosus (L.) All.}

The species is native to South Africa. Its expansion beyond the native range began centuries ago, and it has reached subtropical areas of Africa and Asia, then the European Mediterranean and North America (Schmid 2012).

We found this species on railroad rocks in two places in Moldova.

1. Cahul District, Greceni (Гречень), along railroad tracks, $45.76758^{\circ} \mathrm{N}$, $28.52750^{\circ} \mathrm{E}$ (14 July 2018) (BP).

2. Cahul District, near Slobozia Mare (САобоэня Mape) along railroad tracks, $45.59878^{\circ} \mathrm{N}, 28.16167^{\circ} \mathrm{E}$ (14 July 2018 ).

The species is included in the list of NEGRU (2007), and mentioned from further places in the country by MÂRzA (2010). Typically it occurs in the southern parts of the country (SHABANOvA et al. 2014).

\section{Rumex thyrsiflorus Fingerh.}

The species is native to Europe.

We found it along the roadside in one locality in Moldova.

1. Gagauzia, Comrat (Komrat, Комрат), along roadside, $46.29986^{\circ} \mathrm{N}$, $28.65531^{\circ} \mathrm{E}$ (13 July 2018) (BP).

The species is included in the list of NEGRU (2007). MÂRZA (2010) did not report it, probably he did not consider it being a synanthropic plant. The species is infrequent in Moldova (e.g. SH ABANova et al. 2014). Based on our own observations in Hungary, the species has recently begun to colonize the road margins and spreads quickly (MOLNÁR et al. 2018). Perhaps its expansion along roads is also expected in Moldova.

\section{DISCUSSION}

There are many ruderal habitats in the Republic of Moldova that are suitable for settling and spreading alien plants. Field cultivation is taking place in large areas, there is an extended railway and road network, cities are growing 
and alien species are spreading in these habitats. Some taxa arrive from the west and spread to the east (e.g. Euphorbia maculata), while others turn from east to west (e.g. Grindelia squarrosa). This latter spreading route may cause a problem even in Hungary in the near future since a number of new aliens may appear there. Some indigenous species are now becoming invasive (e.g. Rumex thyrsiflorus, Gypsophila perfoliata). The invasive species presented here already cause or will cause serious conservation and economic problems in Moldova and adjoining regions.

Acknowledgements - We are grateful to Melinda Juhász for her many-sided assistance and to Zoltán Barina for help with writing this article. Travel costs of Dániel Pifkó were supported by the foundation "Magyar Természettudományi Múzeumért Alapítvány".

Összefoglaló: A tanulmány 11 idegenhonos növényfajt mutat be, melyek közül kettőt első alkalommal jelzünk Moldova területéröl (Euphorbia maculata, Gaillardia pulchella), egyet pedig eddig csak botanikus kertből ismertek (Oenothera glazioviana), további 8 fajnak néhány lelőhelyét ismertetjük (Amaranthus powelii, Centaurea diffusa, Grindelia squarrosa, Gypsophila perfoliata, Ruta graveolens, Silphium perfoliatum, Sorghum halepense és Tragus racemosus). Bemutatunk továbbá egy őshonos, de inváziósan viselkedő fajt is (Rumex thyrsiflorus). Elsősorban közutak mellett, vasútvonalak mentén és településeken gyüjtöttünk, ritkábban természetes élőhelyeken is. Célunk jelenleg nem egy összefoglaló tanulmány elkészítése volt, csupán szórványadataink közlése. A herbáriumi bizonyító példányokat a Magyar Természettudományi Múzeum Növénytárának Herbarium Generale (BP) gyüjteményében helyeztük el.

\section{REFERENCES}

Abduloyeva O. S. \& Karpenko N. I. (2009): Occurrence of alien invasive plant species in vegetation syntaxa of Ukraine. (Трапляння чужинних інвазійних рослин в синтаксонах рослинності України). - Chorn. Bot. J. 5(2): 189-198.

ABduloyeva O. S. \& KARPENKO N. I. (2012): Justification of invasiveness criteria for alien plant species in Ukraine. (Обгрунтування критеріїв інвазійного потенціацу чужинних видів рослин в Україні.). - Chorn. Bot. J. 8(2): 252-256.

Aellen P. \& Akeroyd J. R. (1993): Amaranthus L. - In: Tutin T. G. et al. (eds): Flora Europaea 1. 2nd ed. - Cambridge University Press, Cambridge, pp. 130-132.

Anastasiu P., Negrean G., Smarandache D., Lițescu S. \& Basnou C. (2014): Neophytes in protected areas. Case study: the Danube Delta Biosphere Reserve. - Acta Horti Bot. Bucurest. 41: 41-68.

Barkoudah Y. I., Chater A. O. \& Akeroyd J. R. (1993): Gypsophila L. - In: Tutin T. G. et al. (eds): Flora Europaea 1. 2nd ed. - Cambridge University Press, Cambridge, pp. 219-222.

BÁtori Z., ERDÖs L. \& SOMLYAY L. (2012): Euphorbia prostrata (Euphorbiaceae), a new alien in the Carpathian Basin. - Acta Bot. Hung. 54(3-4): 235-243. https://doi.org/10.1556/Abot.54.2012.3-4.2

Chifu T., Mânzu C. \& Zamfirescu O. (2006): Flora și vegetația Moldovei (România). vol. I. Editura Universității „Alexandru Ioan Cuza”, Iași, pp. 367. 
Chytrú M., Pyšek P., Wild J., Pino J., Maskell L. C. \& Vilà M. (2009): European map of alien plant invasions based on the quantitative assessment across habitats. - Diversity and Distributions 15: 98-107. https://doi.org/10.1111/j.1472-4642.2008.00515.x

Ciocârlan V. (2009): Flora ilustrată a României. - Editura Ceres, 3rd ed., București, 1144 pp.

Clayton W. D. (1980): Sorghum Moench. - In: Tutin T. G. et al. (eds): Flora Europaea 5. Cambridge University Press, Cambridge, p. 265.

Csatró A. I. (2014): Pilemia tigrina (Mulsant, 1851), new for the fauna of Republic of Moldova (Coleoptera: Cerambycidae). - Folia Entomol. Hung. 75: 69-72. https://doi.org/10.17112/FoliaEntHung.2014.75.69

CSISzÁr Á. \& KordA M. (eds) (2015): Practical experiences in invasive alien plant control. - Rosalia Handbooks. Duna-Ipoly National Park Directorate, Budapest, 241 pp.

DEgEN Á. (1907): Az Euphorbia maculata L. (E. thymifolia auct. europ. non Burm.) hazánknak egy új bevándorolt gyomja. - Magyar Bot. Lapok 6: 47-50.

Denisow B., Wrzesień M., Mamchur Z. \& Chuba M. (2017): Invasive flora within urban railway areas: a case study from Lublin (Poland) and Lviv (Ukraine) - Acta Agrobot. 70(4): 1727. https://doi.org/10.5586/aa.1727

Dostál J. (1976): Centaurea L. - In: Tutin T. G. et al. (eds): Flora Europaea 4. - Cambridge University Press, Cambridge, pp. 254-301.

Dubyna D. V. \& Protopopova V. V. (1984): Euphorbia maculata L. Novyi dlya flory. (Euphorbia maculata L. Новий Аля фмори). - Ukr. Bot. J. 41: 33-36.

ElıÁš P. jun. (2009): First record of Euphorbia maculata L. (Euphorbiaceae) in Slovakia. - Thaiszia 19: $21-25$.

Esler A. E. \& Astridge S. J. (1987): The naturalisation of plants in urban Auckland, New Zealand 2. Records of introduction and naturalisation. - New Zealand J. Bot. 25: 523-537. https://doi.org/10.1080/0028825x.1987.10410084

Essl F., Bacher S., Genovesi P., Hulme P. E., Jeschke J. M., Katsanevakis S., Kowarik I., Kühn I., Pyšek P., Rabitsch W., Schindler S., van Kleunen M., Vilà M., Wilson J. R. U. \& RichaRdson D. M. (2018): Which taxa are alien? Criteria, applications, and uncertainties. - BioScience 68: 496-509. https://doi.org/10.1093/biosci/biy057

Geideman T. S. (1986): Opredelitel vyssikh Rastenij Moldavskoy SSR. (Onpeделитель высших растений Молдавской ССР). - Štiinca, Kišinev, 641 pp.

Gleason H. A. \& Cronquist A. (1991): Manual of vascular plants of northeastern United States and adjacent Canada. 2nd ed. - The New York Botanical Garden, New York, 910 pp.

GogA I. D. (1960): Euphorbia maculata L. și Lepidium virginicum L. și râspândirea lor în Banat. Comunic. bot., SSNG 1957-1959: 337-339.

Hansen A. (1976a): Gaillardia Foug. - In: Tutin T. G. et al. (eds): Flora Europaea 4. - Cambridge University Press, Cambridge, p. 144.

Hansen A. (1976b): Grindelia Willd. - In: Tutin T. G. et al. (eds): Flora Europaea 4. - Cambridge University Press, Cambridge, p. 109.

Holm L. G., Pancho J. V., Herberger J. P. \& Plucknett D. L. (1979): A geographical atlas of world weeds. - John Wiley \& Sons Ltd., New York, 391 pp.

JEHLí́ K V., MÁJE KovÁ J. \& ZALIBERovÁ M. (2013): New discovered adventive plants from eastern Slovakia. - Thaiszia 23(1): 61-66.

Krukova G. M. \& Bondarenko O. J. (2014): Basic data about the synanthropic flora of the territory of “Tuzlovski lymany” National park. (Первинні відомості про синантропну фмору території Націонацьного природного парку (Тузцовські мимани)). - Chorn. Bot. J. 10(1): 101-113. https://doi.org/10.14255/2308-9628/14.101/10. 
Mamchur Z., Chuba M. \& Drach Yu. (2017): Mosses and vascular plantson railway tracks in the Lviv city. (Мохоподібні та судинни рослини на території залізниц міста Аьвова). Visnyk of the Lviv University. Series Biology. 75: 54-65. UDK 582:32 (477.53)

MÂRza M. (2010): Flora și vegetația sinantropă necultivată a Republicii Moldova. - manuscript, PhD thesis, Chișinău, 346 pp.

Mârza M., Buracinschi N., Grati V., Mîrza E. \& Mamai I. (2014): Istoria cercetării florei și vegetației sinantrope a Republicii Moldova și a teritoriilor limitrofe. - Studia Univ. Mold. 6: 84-97.

McNeely J. A. (ed.) (2001): The great reshuffling. Human dimensions of invasive alien species. IUCN, Gland and Cambridge, vi + 242 pp.

MELNiK R. P. (2009): An annotated list of the alien plants of urban flora of Mykolayiv. (Конспект аАвентивної фракції урбанофмори Миколаєва). - Chorn. Bot. J. 5(2): 147-162 .

Miron A. (2009): Vegetația luncilor râurilor mici din stînga Prutului de Mijloc. - manuscript, PhD thesis, Chișinău, 253 pp.

Mîrza M., Kuharskaia L. \& Gociu D. (1987): Grindelia squarrosa (Pursh) Dunal na teritorii Moldavii. (Пошнрення Grindelia squarrosa (Pursh) Dun. на території Молдавії). - Ukr. Bot.J. 44(6): 42-44.

Molnár Cs., CsAThó A. I. \& Türke I. J. (2012): Újabb botanikai tanulmányút Etelközbe. Összehasonlító erdőssztyepp-tanulmányok III. - Bot. Közlem. 99: 17-45.

Molnár Cs., Haszonits Gy., Malatinszky Á., Süveges K., Balogh L., Nagy T., Horváth S. \& HUDÁK K. (2018): Pótlások Magyarország edényes növényfajainak elterjedési atlaszához VI. - Kitaibelia 23(1): 87-102. https://doi.org/10.17542/kit.23.87

Molnár Cs., Türke I. J., Kelemen A., Korompai T. \& Schmidt J. (2008): Botanikai tanulmányút Moldovába. Összehasonlító erdőssztyepp-tanulmányok II. - Bot. Közlem. 95(1-2): 127-154.

Negru A. (2007): Determinator de plante din flora Republicii Moldova. - Acad. de Ştiințe a Moldovei, Grădina Botanică, Chișinău, 391 pp.

Negru A., Ştefîrța A., Cantemir V., GÂnju Gh. \& Chendov V. (2006): Lumea vegetală a Moldovei vol. 3. - Ştiința, Chișinău, 208 pp.

OPREA A. (2005): Lista critică a plantelor vasculare din România. - Universității „Alexandru Ioan Cuza", Iași, 668 pp.

PAshinevych N. \& Burda R. (2017): Distribution of alien species from Poaceae and Asteraceae families in the protected areas of Ukrainian forest-steppe. - Thaiszia 27(1): 29-39.

Petrova A., Vladimirov V. \& Georgiev V. (2013): Invasive alien species of vascular plants in Bulgaria. - Bulgarian Academy of Sciences, Sofia, 320 pp.

Pliszko A. (2016): New records of Gypsophila perfoliata (Caryophyllaceae) in Poland. - Acta Mus. Siles. Sci. Natur., 65: 215-218. https://doi.org/10.1515/cszma-2016-0025

Popova E. N. (2003): Flora and vegetation of Kiliya delta of Danube river. (ФАора и растительность Кимийской Аемьты Ауная). - Odesa National University Herald. Ecology 8(11): 106-137. UDK 581.9(477.74)

Pricop E. \& Negrea B.-M. (2018): Considerations concerning the distribution and impact of the most infamous invasive plant species from Bistrita River Basin (Neamt and Suceava Counties, Romania). - Adv. Agric. Bot. Bioflux 10: 40-56.

Protopopova V. V., Shevera M. V. \& Mosyakin S. L. (2006): Deliberate and unintentional introduction of invasive weeds: A case study of the alien flora of Ukraine. - Euphytica 148: 17-33. https://doi.org/10.1007/s10681-006-5938-4 
Rostański K. (2004): Oenothera in Moldova. - In: Rostańs Ki K., Dzhus M., Gudžinskas Z., Rostański A., Shevera M., Šulcs V. \& Tokhtar V.: The genus Oenothera L. in Eastern Europe. W. Szafer Institute of Botany, Polish Academy of Science, Kraków, pp. 102-103.

Rostański K., Rostański A., Shevera M. \& Tokhtar V. (2004): Oenothera in Ukraine. - In: Rostański K., Dzhus M., Gudžinskas Z., Rostański A., Shevera M., Šulcs V. \& Toкнtar V.: The genus Oenothera L. in Eastern Europe. - W. Szafer Institute of Botany, Polish Academy of Science, Kraków, pp. 78-97.

Rostański K., Rostański A., Gerold-Śmietańska I. \& Wąsowicz P. (2010): EveningPrimroses (Oenothera) Occuring in Europe. - W. Szafer Institute of Botany, Polish Academy of Science, Katowice, Kraków, 160 pp.

SÂrbu I., Ştefan N. \& Oprea A. (2013): Plante Vasculare din România: determinator ilustrat de teren. - Victor B Victor, București, $1320 \mathrm{pp}$

SснміDт D. (2012): Bugás tövisperje (Tragus racemosus [L.] All.). - In: CsiszÁr Á. (ed.): Inváziós növényfajok Magyarországon. Nyugat-magyarországi Egyetem Kiadó, Sopron, pp. 334-339.

Shabanova T. I., Izverskaya T. D. \& Ghendov V. S. (2014): Flora i Rastitel' nost' Budzhatskikh Stepey Respubliki Moldova. (Флора и растительность Буджакских степей Республики Молдова). - Eco-TIRAS, Kišinev, 324 p.

SîRBU C. \& OpREA A. (2008): Two alien species in the spreading process in Romania: Reynoutria $\times$ bohemica Chrtek \& Chrtková and Grindelia squarrosa (Pursh) Dunal. - Cerc. Agron. Moldova 41: 41-50.

Sîrbu C. \& Oprea A. (2010): New and rare plants from the flora of Moldavia (Romania). - Cerc. Agron. Moldova 43: 31-42.

Sîrbu C., Oprea A., Samuil C. \& TĂnase C. (2012): Neophyte invasion in Moldavia (Eastern Romania) in different habitat types. - Folia Geobot. 47: 215-229. https://doi.org/10.1007/s12224-011-9112-y

Skvortsov A. K. (1994): Genus Oenothera (Onagraceae) in the former Soviet Union: taxonomy and distribution. (РоА Oenothera (семейство Onagraceae) на территории бывшего СССР: систематика и распространение). - Bull. Moscow Soc. Natur., Biol. ser. 99: 362-364.

Sмith A. R. \& Tutin T. G. (1968): Euphorbia L. - In: Tutin T. G. et al. (eds): Flora Europaea 2. - Cambridge University Press, Cambridge, pp. 213-226.

SomLyay L. (2009): Alien Gypsophila taxa in the flora of Hungary. - Studia bot. hung. 40: 173-180.

ŚWIĘS F. \& WRZESIEŃ M. (2002): Rare vascular plants of railway areas in Central-Eastern Poland. I. Lublin Upland, eastern part, Roztocze, Volhynia Upland. - Ann. Unive. Mariae Curie-Sktodowska Sec. C 57: 1-23.

Townsend C. C. (1968): Ruta L. - In: Tutin T. G. et al. (eds): Flora Europaea 2. - Cambridge University Press, Cambridge, p. 227.

Tutin, T. G. (1976): Silphium L. - In: Tutin T. G. et al. (eds): Flora Europaea 4. - Cambridge University Press, Cambridge, p. 142.

Tutin T. G., Burges N. A., Chater A. O., Edmonson J. R., Heywood V. H., Moore D. M., Valentine D. H., Walters S. M. \& Webb D. A. (eds) (1993): Flora Europaea 1. 2nd ed. Cambridge University Press, Cambridge, $581 \mathrm{pp}$.

Tutin T. G., Heywood V. H., Burges N. A., Moore D. M., Valentine D. H., Walters S. M. \& Webв D. A. (eds) (1964-1980): Flora Europaea 1-5. 1st ed. - Cambridge University Press, Cambridge, 464, 455, 370, 523, 467 pp.

Vladimirov V. \& Petrova A. S. (2012): Grindelia squarrosa: a new alien species for the Bulgarian flora. - Phytol. Balcanica 18(3): 315-318. 
Wiersema J. H. \& LEÓN B. (2013): World economic plants: a standard reference. 2nd ed. - CRC Press, Boca Raton, London, New York, 1336 pp.

WitTENBERg R. \& CocK M. J. W. (eds) (2001): Invasive alien species: a toolkit of best prevention and management practices. - $\mathrm{CAB}$ International, Wallingford, Oxon, $228 \mathrm{pp}$.

Yakubenko B. Y., Churilov A. M., Tertyshnil A. P. \& Yarmolenko A. K. (2014): The synantropization analysis of flora of long-fallow lands in the forest-steppe of the Kyiev Region. - Biol. Res. Nat. Manage. 6(3-4): 5-10. UDC 581.526.34:332.32

(submitted: 30.04.2019, accepted: 05.06.2019) 